\title{
Morphological Features of Plants and Yield of Sunflower Hybrids Cultivated in the Northern Part of the Forest-Steppe of Ukraine
}

\author{
S. Kalenska, A. Ryzhenko, N. Novytska, L. Garbar, T. Stolyarchuk, V. Kalenskyi, \\ 0. Shytiy
}

National University of Life and Environmental Sciences of Ukraine, Department of Plant Science, Kyiv, Ukraine

Email: wisssy@bigmir.net

How to cite this paper: Kalenska, S., Ryzhenko, A., Novytska, N., Garbar, L., Stolyarchuk, T., Kalenskyi, V. and Shytiy, O. (2020) Morphological Features of Plants and Yield of Sunflower Hybrids Cultivated in the Northern Part of the Forest-Steppe of Ukraine. American Journal of Plant Sciences, 11, 1331-1344.

https://doi.org/10.4236/ajps.2020.118095

Received: July 10, 2020

Accepted: August 22, 2020

Published: August 25, 2020

Copyright $\odot 2020$ by author(s) and Scientific Research Publishing Inc. This work is licensed under the Creative Commons Attribution International License (CC BY 4.0).

http://creativecommons.org/licenses/by/4.0/

(c) (i) Open Access

\begin{abstract}
In Ukraine, a sunflower is the main oil crop from which more than $90 \%$ of vegetable fats are produced. An increase in production is due to the expansion of cultivation area, which necessitates research on sunflower hybrids adaptability in the northern regions of Ukraine, where in recent decades, there has been a significant change of weather conditions and which may be favorable for its cultivation. The research was carried out in the Northern part of the Forest-Steppe of Ukraine on light loam chernozems. Reaction to growing conditions of four hybrids was studied by establishing the stability and plasticity of hybrids in terms of yield formation due to changes in morphological characteristics of plants. Yield potential realization is high enough, which is provided by sufficient amounts of positive, active, effective temperatures and precipitation. Calculation of the coefficients of plasticity and stability allows identifying stable sunflower hybrids, hybrids with a high level of plasticity, and recommending them to production. The yield of early-maturing hybrid Ukrainskyi F1 increases rectilinearly with plant density increasing $(\mathrm{r}=$ 0.977 - 0.998), while hybrids P63LL06 $(r=0.651-0.882)$; NK Ferti $(r=0.589$ - 0.846), and NK Brio $(r=0.689-0.804)$ form a higher yield at standing densities up to 60 thousand plants per hectare, and with further thickening, the yield decreases. With the thickening of sowings, the height of all hybrids plants increases $(r=0.97-0.99)$, and there is a decrease in the number of seeds per anthode, and the weight of 1000 seeds. Sunflower hybrids can be divided into the groups according to the peculiarities of yield formation due to morphological features: 1) yield increases only due to sowings' thickeningUkrainskyi F1; 2) combined efficiency-increasing sowings' density to 60 thousand plants/ha and generative organs formation-NCKBrio; 3) hybrids of intermediate type-NK Ferti and P63LL06.
\end{abstract}




\section{Keywords}

Sunflower, Yield, Plasticity, Stability, Plant Height, The Weight of 1000 Seeds, Individual Plant's Productivity

\section{Introduction}

Global change of climate and weather conditions, growing needs of mankind for food, energy plant resources, raw materials for industrial processing, and other urgent human needs requires crop production expansion [1] [2] [3] [4] [5]. At the same time, crop production should be economically and environmentally feasible. In recent years, Ukraine has been expanding the production of an important oil crop of universal use-sunflower [6]. The sown areas of sunflower (Helianthus annuus) - a traditional culture of the Steppe zone are actively moving to the Northern regions of Ukraine [7]. Establishing of hybrids' adaptability, peculiarities of their productivity formation, dependences of vegetative and generative organs formation, depending on weather and technological factors is relevant.

\section{Literature Survey}

\subsection{Significance and State of Sunflower Production}

Sunflower is a crop that is widespread in the southern regions of Europe and Ukraine in particular. In recent years, due to significant changes in weather conditions-increasing in air temperature, and a prolongation of the period with air temperatures above $8^{\circ} \mathrm{C}-10^{\circ} \mathrm{C}$ in the northern regions, there has been an expansion of the geographical zone of sunflower cultivation. Establishing the features of sunflower cultivation and development of adaptive cultivation technologies is an important area of research for the northern regions of Europe and Ukraine [8].

In Ukraine, the main oil crop is a sunflower, which produces over $90 \%$ of vegetable fats. Gross sunflower production in Ukraine has increased to 12 million tons in recent years. Between 2010 and 2019, the area under sunflower in Ukraine increased by almost one and a half million hectares and reached 6.1 million hectares. Ukraine is a leader in sunflower production and the largest exporter of sunflower oil in the world-5, 6 million tons (57\% of total exports in 2018). The gross harvest of sunflower seeds increase was mainly due to the expansion of sown areas. A feature of the soil-climatic zone of the Steppe of Ukraine, where sunflower is mainly grown, is an insufficient amount of precipitation with a significant potential of solar energy. Due to such natural features, almost every year there is an acute shortage of soil moisture, which prevents the planned level of yield [9]. With high plowing levels of soils and oversaturation of crop rotations by sunflower, specific diseases and pests are spread. All this necessitates research on the adaptability of sunflower hybrids in the Northern regions of Ukraine, where in recent decades there has been a significant change in 
weather conditions and which may be favorable for sunflower growing.

\subsection{The Adaptability of Sunflower Plants to Growing Conditions}

The task of creating and implementing in production hybrids with high yield potential with optimization of growing conditions is complicated by the problem of ecological adaptation: the potential of production conditions can't grow adequately to the growth of genetically determined yield potential of varieties [10] [11] [12]. The ability to economically and efficiently use environmental factors is a highly adaptive genotype property [13]. The adaptability of hybrids is an extremely important feature of variable abiotic and biotic environmental factors [14] [15]. Sunflower is a culture of the temperate zone and is quite flexible to weather and soil conditions [16] [17]. Sunflower is a salt-tolerant crop [18]. Sunflower is characterized by high adaptability and yield [8]. Optimally formed plant population of sunflower influence the quality of seed for processing [19] [20].

\subsection{Morphological Features of Plants, Sunflower Yield Depending on Plants' Density}

The level of varieties' and hybrids' biological potential realization depends on both-growing technology and climatic conditions of a particular year and their interaction [21] [22] [23] [24]. Sunflower yield is determined by several factors, among which the role of hybrid and plants' standing density are among the determinants [25] [26]. Agrocenosis formation with an optimal plant density and optimal nutrients supply provides an increase in its productivity [27] [28].

Morphological characteristics of the plant are varietal characteristics, but under the influence of environmental factors and cultivation technologies, they may change [29]. Under the influence of nitrogen fertilizers, a yield increase of sunflower hybrids, an increase in the anthode diameter was recorded [30] [31] [32]. The height of plants with plants standing density increasing usually increases, especially with using irrigation [33]. There is also a decrease in the weight of 1000 seeds and seeds number from the anthode [34]. However, with plant density increasing, competition for light between plants increases, which leads to a decrease in vegetative and reproductive plasticity of the plant [35], while lower plant density leads to reduced light absorption by plants what leads to a reduction in yield per unit area [36] [37] [38]. Theoretical studies and practical experience have shown that high yields per unit area are usually associated with low plant competitiveness due to reduced anthode diameter, plant biomass, weight of 1000 seeds, seed yield per plant, unsaturated fatty acids [39] [40].

\section{Conditions and Methods of Research}

In the Northern part of the Left Bank Forest-Steppe of Ukraine (Bakhmach, Chernigiv region (51.1513819, 32.8623028)) during 2016-2018 field studies were conducted for the identification sunflower hybrids of different ecotype by mor- 
phological characteristics, stability, and yield plasticity under variable weather conditions. Multifactor field experiment was based on the following scheme: factor A-"hybrid”: "Ukrainskyi F1", "P63LL06", "NK Brio", "NK Ferti”; factor B-“density of plants' standing": 50, 55, 60, 65 thousand pieces/ha. The area of the accounting plot is $50 \mathrm{~m}^{2}$, repeating is quadruple.

In the experiment, hybrids of different selection were used, which differ in growth intensity at the initial microstages of development, which requires additional research for sunflower cultivation in the northern regions of Ukraine:

Ukrainskyi F1 (selection of Ukraine) - an early-ripening hybrid-develops rapidly in the initial microstages.

P63LL06 (selection of Pioneer) - a medium-early-ripening hybrid with sufficiently high growth energy at the initial microstages.

NK Brio (selection of Syngenta) - a medium-ripening hybrid-early in its maturity group. Initial growth is slow.

NK Ferti (selection of Syngenta) - a medium-ripe hybrid with medium growth energy in the initial stages.

Originators of hybrids give recommendations on plant density, but depending on weather conditions and soil, hybrids respond differently to crop density, so identifying the optimal crop density of a particular hybrid is extremely important. For the study, we chose a step to change the density of standing plants with a difference of 5 thousand plants/ha from the density recommended by the authors of hybrids.

The soil of experimental plots is light loam chernozem with humus content 2.98\%. The reaction of soil solution is close to neutral, $\mathrm{pH}-5.9-6.2$. The weighted average content of mobile forms of phosphorus is $132 \mathrm{mg} / \mathrm{kg}$ of soil, exchangeable potassium is $94 \mathrm{mg} / \mathrm{kg}$ of soil, the content of exchangeable calcium and magnesium is increased, respectively 10.6 and $2.2 \mathrm{mg}$-eq/100 g of soil. Soil quality-69 points, and therefore in general the soil of the experimental area has favorable agrophysical properties and relatively high natural fertility, which allows growing sunflowers successfully.

The field was plowed to a depth $28-30 \mathrm{~cm}$, and after plowing, for weeds destroying and leveling the soil, cultivation to a depth $8-10 \mathrm{~cm}$ was used. In the spring-soil moisture conservation by spring harrowing. Fertilized by anhydrous ammonia-123.3 kg/ha in the nitrogen active substance; under pre-sowing cultivation was applied $\mathrm{N}_{16} \mathrm{P}_{38} \mathrm{P}_{58}$ in the active substance. During sowing, a complex fertilizer $\mathrm{N}_{8} \mathrm{P}_{24} \mathrm{~K}_{24} \mathrm{~S}_{5}$, in the active substance, was applied in the row area.

Soil herbicide Primextra TZ Gold 500 was applied at the rate 4 1/ha. Fungicide Propulse at the rate $11 /$ ha with simultaneous application of YaraVita BORTRAC 150 at the rate 1 1/ha was used for prevention diseases. The sunflower hybrids were sown in the third decade of April: April 20th; April 22nd; April 25th, respectively, in 2016, 2017, 2018. Seedlings in all three years of research appeared on May 2-3. Hybrids reached full maturity (15\% of seed moisture) in the last decade of August-after August 25th. The sunflower was harvested with 7\% of seed moisture in the I - II decade of September. 
Determination of stability and plasticity of hybrids by yield was performed according to the Eberhard-Russell method, while for the criterion "point" we used the criterion "weather conditions of the year" [41]. In this modification, we determined the stability and plasticity of the hybrids relative to the meteorological conditions of the research site.

Sunflower yields were accounted for each site by combine harvesting.

Statistical data processing was performed using the software package SAS 9.4.

\section{Results of Research}

\subsection{Weather Conditions of the Research Region}

The climate of the district is temperate-continental. The average temperature in July is $+20^{\circ} \mathrm{C}$. The average January temperature is between $-6^{\circ} \mathrm{C}$ and $-8^{\circ} \mathrm{C}$. The growing season lasts an average of $200-210$ days. The period, when the average daily temperature exceeds $+15^{\circ} \mathrm{C}$, is approximately 110 days. Annual sum of temperatures exceeding $+10^{\circ} \mathrm{C}$ is $2500-2600$. Period without light frosts on the soil surface lasts about $135-140$ days. Precipitation averages about $550-600$ $\mathrm{mm}$. The biggest amount of precipitation, about $75 \%$, falls from April to October.

The analysis of average daily air temperatures was performed in the matching of long-term data to 2005-2015. The average daily temperature only in April steadily passes over $+10^{\circ} \mathrm{C}$, but the dynamics of temperature rise over the years are quite different. The average daily air temperature is quite moderate and during the period of active sunflower's vegetation varies from $14.0^{\circ} \mathrm{C}$ to $21.6^{\circ} \mathrm{C}$. The sum of temperatures, both at a biological minimum temperature $10^{\circ} \mathrm{C}$ and $5^{\circ} \mathrm{C}$, corresponds to the biological needs of sunflower plants and is not a limiting factor of cultivation. The sum of thermal units for the period April-October, on average for three years, is 3780 . During the period of active sunflower vegetation (April-August) the sum of thermal units is 2868 - 3258, significantly exceeding the sum of active and effective temperatures at biologically active temperatures $5^{\circ} \mathrm{C}$ and $10^{\circ} \mathrm{C}$.

In the research area, the maximum temperatures are quite comfortable-do not exceed $30^{\circ} \mathrm{C}$, with some exceptions (the second decade of August $2017-36^{\circ} \mathrm{C}$ ). Temperatures in the range up to $30^{\circ} \mathrm{C}$ promote the formation and development of generative organs.

The average amount of precipitation according to long-term data is $556 \mathrm{~mm}$, in the years of research it was: 849,592, $516 \mathrm{~mm}$, respectively, in 2016, 2017, 2018. However, during the period of sunflower's active vegetation (May-September) precipitation was 390, 247, $211 \mathrm{~mm}$, respectively, in 2016, 2017, 2018. Hybrids differ significantly by their response to moisture, maximum and minimum temperatures, and other factors.

\subsection{Plasticity and Stability of Hybrids by Yield}

Growing of sunflower hybrids in the Northern part of the Left-Bank For- 
est-Steppe of Ukraine produces a consistently high yield. During 2016-2018, yield of hybrids ranged: Ukrainskyi F1-2.16 - 3.11; P63LL06-2.58 - 3.52; NK Brio-3.20 - 4.12; NK Ferti-2.79 - 3.79 t/ha (Table 1). The productivity of sunflower is determined by genetically determined features, but within certain limits, they can change under the influence of environmental factors.

Calculated coefficients of plasticity and yield stability indicate favorable conditions for yields of sunflower hybrids formation.

Stability coefficient for hybrid "Ukrainskyi F1" was 1.68 - 2.30; "P63LL06"2.51 - 3.14; "NK Brio"-3.15 - 4.63; "NK Ferti"-2.70 - 3.75.

The early-ripening hybrid "Ukrainskyi F1" is approaching its maximum in terms of the level of yield potential realization, in the conditions of research. Coefficients of plasticity among the studied hybrids are the lowest-2.36 - 2.97 and with an average yield of $2.41-2.81$ t/ha shows bigger stability-1.68 - 2.30 compared to other sunflower hybrids. Hybrid "NK Brio" is highly plastic and, as the results show, the yield potential of this hybrid in the Northern part of the Left-Bank Forest-Steppe has not been fully realized. The maximum yield of the hybrid was formed with a rate of 60 thousand plants/ha - $3.93 \mathrm{t} / \mathrm{ha}$ and the coefficient of plasticity increased to 4.84 with a stability coefficient 4.63 .

Table 1. Plasticity and yield stability of sunflower hybrids.

\begin{tabular}{|c|c|c|c|c|}
\hline Hybrid & $\begin{array}{l}\text { The density of plants' } \\
\text { standing, thousand pieces/ha }\end{array}$ & $\begin{array}{l}Y i^{1} \\
t / h a\end{array}$ & $b$ & $\sigma d^{2}$ \\
\hline \multirow[t]{4}{*}{ Ukrainskyi F1 } & 50 & 2.41 & 2.36 & 1.68 \\
\hline & 55 & 2.55 & 2.69 & 1.83 \\
\hline & 60 & 2.70 & 2.74 & 1.98 \\
\hline & 65 & 2.81 & 2.97 & 2.30 \\
\hline \multirow[t]{4}{*}{ P63LL06 } & 50 & 2.91 & 2.93 & 2.51 \\
\hline & 55 & 3.02 & 3.30 & 2.68 \\
\hline & 60 & 3.37 & 4.14 & 3.14 \\
\hline & 65 & 3.20 & 3.93 & 3.02 \\
\hline \multirow[t]{4}{*}{ NK Brio } & 50 & 3.32 & 4.34 & 3.15 \\
\hline & 55 & 3.61 & 4.50 & 3.53 \\
\hline & 60 & 3.93 & 4.84 & 4.63 \\
\hline & 65 & 3.67 & 4.34 & 3.95 \\
\hline \multirow[t]{4}{*}{ NK Ferti } & 50 & 3.00 & 3.29 & 2.7 \\
\hline & 55 & 3.18 & 3.59 & 3.01 \\
\hline & 60 & 3.57 & 4.33 & 3.75 \\
\hline & 65 & 3.34 & 3.77 & 3.20 \\
\hline
\end{tabular}

Notes: ${ }^{1} \mathrm{Yi}$-average yield; ${ }^{2} \mathrm{~b}-$ coefficient of plasticity; ${ }^{3} \sigma \mathrm{d}^{2}-$ coefficient of stability. 


\subsection{Structural Components of Sunflower Hybrids' Yields}

The yield of sunflower hybrids significantly depends on plants' standing density and this is the predominant factor in yields' formation. The individual yield of plant decreases due to crop thickening, but due to the increase of plants' number in the area, the yield also increases.

Reaction to the sowings' thickening was manifested through a change in the yield structure. The early-maturing hybrid "Ukrainskyi F1" formed a lower yield compared to other hybrids (Table 2).

Yield of early-ripening hybrid "Ukrainskyi F1" increases rectilinearly with plant density increasing $(r=0.977-0.998)$, while hybrids P63LL06 $(r=0.651$ 0.882); "NK Ferti" ( $\mathrm{r}=0.589-0.846)$ and "NK Brio" ( $\mathrm{r}=0.689-0.804)$ form a higher yield at standing densities up to 60 thousand plants per hectare, and with further thickening the yield decreases.

Height of sunflower plants is largely determined by the morphological features of a hybrid, varying slightly over the years: "Ukrainskyi F1" - 173.5 - 177.8; “P63LL06"-184.1 - 188.4; “NK Brio"-167.5 - 171.5; "NK Ferti”-181.9 - 187.2 $\mathrm{cm}$ (Tables 2-5). With sowings thickening, the plants' height of all hybrids increases $(r=0.97-0.99)$.

Hybrid "P63LL06" occupied an intermediate position between hybrids forming a yield in a favorable for weather conditions year (2018) from 3.26 to $3.52 \mathrm{t} / \mathrm{ha}$ and in years with less favorable conditions-from 2.58 to $3.20 \mathrm{t} / \mathrm{ha}$. The diameter of the anthode varies from 20.1 to $25.9 \mathrm{~cm}$. The number of seeds in the anthode varies from 654 to 712 pieces, and the weight of seeds from the anthode is 44.5 - 54.8 grams. Plants of the hybrid have a stable height, which ranges from 184.1 to $187.8 \mathrm{~cm}$ (Table 3 ).

Hybrid "NK Brio" in all years of research and at different densities stood the highest yields (Table 4).

The hybrid formed anthodes with the largest diameter among the studied hybrids-from 24.0 to $27.7 \mathrm{~cm}$, in which 748 - 831 achenes were differentiated, and their weight was 53.1 - $65.3 \mathrm{~g}$. Quantitative reduction of yields structural components occurred with the thickening of sowings and less precipitation during the period of achenes' differentiation. The plants of hybrid "NK Brio" were the lowest compare to other hybrids- $167.5-171.5 \mathrm{~cm}$, but the stem diameter was the largest $-2.9-3.5 \mathrm{~cm}$.

Hybrid "NK Ferti" yielded slightly relative to the yield of hybrid "NK Brio" (Table 5). According to the morphological features, plants of hybrid "NK Brio" differed from "NK Brio". The diameter of the anthode varied from 18.5 to 23.4 $\mathrm{cm}$. The number of achenes in the anthode $656-706$, and the mass of achenes in the anthode-45.5 - $54.4 \mathrm{~g}$. The mass of 1000 seeds was 69 - 77. Dependencies between yield and structure components show, that a close correlative positive relationship was established for yield and plants density in the sowings $(r=0.589$ - 0.846); plant height $(r=0.616-0.883)$; leaf surface index $(r=0.633-0.851)$. However, these connections are not as close as in the hybrid "Ukrainskyi F1". 
Table 2. Morphological features and yield of hybrid Ukrainskyi F1.

\begin{tabular}{|c|c|c|c|c|c|c|c|}
\hline Year & $\begin{array}{l}\text { The density of the plants' } \\
\text { standing, thousand } \mathrm{pc} / \mathrm{ha}\end{array}$ & $\begin{array}{l}\text { Yield, } \\
\text { t/ha }\end{array}$ & $\begin{array}{l}\text { Number of seeds, } \\
\text { pc/anthode }\end{array}$ & $\begin{array}{l}\text { Mass of seed, } \\
\text { g/anthode }\end{array}$ & $\begin{array}{l}\text { The diameter of } \\
\text { anthode, } \mathrm{cm}\end{array}$ & $\begin{array}{c}\text { Plant height, } \\
\mathrm{cm}\end{array}$ & $\begin{array}{c}\text { The diameter of } \\
\text { the stem, } \mathrm{cm}\end{array}$ \\
\hline \multirow{5}{*}{2016} & 50 & $2.32^{\mathrm{c}}$ & $569^{\mathrm{b}}$ & $42.1^{\mathrm{b}}$ & $24.2^{\mathrm{bc}}$ & $173.5^{\mathrm{b}}$ & $2.7 \mathrm{~b}$ \\
\hline & 55 & $2.44^{\mathrm{b}}$ & $556^{\mathrm{b}}$ & $40.0^{\mathrm{b}}$ & $22.5^{\mathrm{bc}}$ & $174.8^{\mathrm{b}}$ & $2.7^{\mathrm{b}}$ \\
\hline & 60 & $2.68^{\mathrm{a}}$ & $550^{\mathrm{b}}$ & $38.5^{\mathrm{a}}$ & $21.6^{\mathrm{bc}}$ & $175.6^{\mathrm{b}}$ & $2.4^{\mathrm{bc}}$ \\
\hline & 65 & $2.79^{\mathrm{a}}$ & $544^{\mathrm{b}}$ & $37.5^{\mathrm{b}}$ & $20.3^{b c}$ & $176.3^{\mathrm{b}}$ & $2.1^{\mathrm{bc}}$ \\
\hline & Average & $2.56^{\mathrm{a}}$ & $555^{\mathrm{b}}$ & $39.5^{\mathrm{b}}$ & $22.2^{\mathrm{bc}}$ & $175.1^{\mathrm{b}}$ & $2.5^{\mathrm{a}}$ \\
\hline \multirow{5}{*}{2017} & 50 & $2.16^{c}$ & $561^{\mathrm{b}}$ & $41.0^{\mathrm{ab}}$ & $23.9^{\mathrm{b}}$ & $175.2^{\mathrm{b}}$ & $2.8^{\mathrm{ab}}$ \\
\hline & 55 & $2.26^{b c}$ & $549^{\mathrm{bc}}$ & $39.0^{\mathrm{ab}}$ & $22.3^{\mathrm{b}}$ & $175.8^{\mathrm{b}}$ & $2.6^{\mathrm{ab}}$ \\
\hline & 60 & $2.40^{\mathrm{b}}$ & $542^{\mathrm{b}}$ & $37.4^{\mathrm{a}}$ & $21.2^{\mathrm{b}}$ & $176.6^{\mathrm{b}}$ & $2.5^{\mathrm{a}}$ \\
\hline & 65 & $2.53^{\mathrm{a}}$ & $518^{\mathrm{b}}$ & $34.7^{\mathrm{a}}$ & $20.4^{\mathrm{b}}$ & $177.1^{\mathrm{b}}$ & $2.3^{\mathrm{b}}$ \\
\hline & Average & $2.34^{\mathrm{b}}$ & $543^{\mathrm{b}}$ & $38.0^{\mathrm{b}}$ & $21.9^{\mathrm{b}}$ & $176.2^{\mathrm{b}}$ & $2.6^{\mathrm{ab}}$ \\
\hline \multirow{5}{*}{2018} & 50 & $2.75^{c}$ & $583^{\mathrm{b}}$ & $43.1^{\mathrm{bc}}$ & $24.6^{\mathrm{b}}$ & $176.1^{\mathrm{b}}$ & 2.7 \\
\hline & 55 & $2.9^{\mathrm{b}}$ & $568^{\mathrm{bc}}$ & $41.5^{\mathrm{bc}}$ & $23.8^{\mathrm{b}}$ & $176.4^{\mathrm{b}}$ & $2.7^{\mathrm{b}}$ \\
\hline & 60 & $3.02^{\mathrm{a}}$ & $554^{\mathrm{c}}$ & $38.8^{\mathrm{bc}}$ & $23.2^{\mathrm{b}}$ & $177.1^{\mathrm{b}}$ & $2.5^{\mathrm{b}}$ \\
\hline & 65 & $3.11^{\mathrm{a}}$ & $550^{c}$ & $38.5^{\mathrm{a}}$ & $22.4^{\mathrm{b}}$ & $177.8^{c}$ & $2.4^{\mathrm{b}}$ \\
\hline & Average & $2.96^{\mathrm{a}}$ & $564^{\mathrm{c}}$ & $40.5^{\mathrm{bc}}$ & $23.5^{\mathrm{b}}$ & 176.9 & $2.6^{\mathrm{b}}$ \\
\hline
\end{tabular}

Note: Significant differences $(\mathrm{p}<0.05)$ between the values in the column are identified by different letters.

Table 3. Morphological features and yield of hybrid P63LL06.

\begin{tabular}{|c|c|c|c|c|c|c|c|}
\hline Year & $\begin{array}{l}\text { The density of plants' } \\
\text { standing, thousand } \mathrm{pc} / \mathrm{ha}\end{array}$ & $\begin{array}{l}\text { Yield, } \\
\text { t/ha }\end{array}$ & $\begin{array}{l}\text { Number of seeds, } \\
\text { pc/anthode }\end{array}$ & $\begin{array}{l}\text { Mass of seed, } \\
\text { g/anthode }\end{array}$ & $\begin{array}{l}\text { The diameter of } \\
\text { anthode, } \mathrm{cm}\end{array}$ & $\begin{array}{l}\text { Plant height, } \\
\mathrm{cm}\end{array}$ & $\begin{array}{c}\text { The diameter of } \\
\text { the stem, } \mathrm{cm}\end{array}$ \\
\hline \multirow{5}{*}{2016} & 50 & $2.88^{\mathrm{b}}$ & $707^{b}$ & $53.7^{\mathrm{b}}$ & $25.4^{\mathrm{b}}$ & $184.1^{\mathrm{b}}$ & $2.9^{\mathrm{b}}$ \\
\hline & 55 & $2.99^{\mathrm{b}}$ & $698^{\mathrm{b}}$ & $51.0^{\mathrm{b}}$ & $22.7^{\mathrm{b}}$ & $185.8^{\mathrm{b}}$ & $2.7^{\mathrm{b}}$ \\
\hline & 60 & $3.48^{\mathrm{a}}$ & $697^{\mathrm{b}}$ & $50.2^{\mathrm{b}}$ & $22.0^{\mathrm{b}}$ & $187.2^{\mathrm{b}}$ & $2.5^{\mathrm{b}}$ \\
\hline & 65 & $3.20^{\mathrm{a}}$ & $667^{\mathrm{b}}$ & $46.0^{\mathrm{b}}$ & $20.1^{\mathrm{b}}$ & $188.4^{\mathrm{b}}$ & $2.4^{\mathrm{b}}$ \\
\hline & Average & 3.14 & $692^{\mathrm{b}}$ & $50.2^{\mathrm{b}}$ & $22.6^{\mathrm{b}}$ & $186.4^{\mathrm{b}}$ & $2.6^{\mathrm{b}}$ \\
\hline \multirow{5}{*}{2017} & 50 & $2.58^{\mathrm{b}}$ & $703^{\mathrm{b}}$ & $52.0^{\mathrm{b}}$ & $25.6^{\mathrm{bc}}$ & $185.1^{\mathrm{bc}}$ & $2.8^{\mathrm{bc}}$ \\
\hline & 55 & $2.75^{\mathrm{b}}$ & $687^{b}$ & $49.5^{\mathrm{ab}}$ & $22.5^{\mathrm{bc}}$ & $186.3^{\mathrm{bc}}$ & $2.8^{\mathrm{bc}}$ \\
\hline & 60 & $3.12^{\mathrm{a}}$ & $672^{b}$ & $47.0^{\mathrm{ab}}$ & $22.4^{\mathrm{b}}$ & $186.9^{\mathrm{bc}}$ & $2.6^{\mathrm{b}}$ \\
\hline & 65 & $3.02^{\mathrm{a}}$ & $654^{\mathrm{ab}}$ & $44.5^{\mathrm{b}}$ & $20.8^{\mathrm{b}}$ & $187.8^{\mathrm{b}}$ & $2.5^{\mathrm{b}}$ \\
\hline & Average & 2.87 & $679^{\mathrm{ab}}$ & $48.2^{\mathrm{ab}}$ & $22.8^{\mathrm{b}}$ & $186.5^{\mathrm{b}}$ & $2.7^{\mathrm{b}}$ \\
\hline \multirow{5}{*}{2018} & 50 & $3.26^{\mathrm{b}}$ & $712^{\mathrm{ab}}$ & $54.8^{\mathrm{ab}}$ & $25.9^{\mathrm{bc}}$ & $185.3^{\mathrm{b}}$ & $2.8^{\mathrm{bc}}$ \\
\hline & 55 & $3.31^{\mathrm{ab}}$ & $704^{\mathrm{ab}}$ & $52.1^{\mathrm{ab}}$ & $25.6^{\mathrm{bc}}$ & $185.7^{\mathrm{b}}$ & $2.7^{\mathrm{b}}$ \\
\hline & 60 & $3.52^{\mathrm{a}}$ & $703^{\mathrm{a}}$ & $51.3^{\mathrm{b}}$ & $23.1^{\mathrm{b}}$ & $186.0^{\mathrm{b}}$ & $2.6^{\mathrm{b}}$ \\
\hline & 65 & $3.38^{\mathrm{a}}$ & $695^{\mathrm{a}}$ & $48.7^{\mathrm{b}}$ & $21.7^{\mathrm{b}}$ & $186.3^{\mathrm{b}}$ & $2.4^{\mathrm{b}}$ \\
\hline & Average & 3.37 & $704^{\mathrm{ab}}$ & $51.7^{\mathrm{b}}$ & $24.1^{\mathrm{b}}$ & $185.8^{\mathrm{b}}$ & $2.6^{\mathrm{b}}$ \\
\hline
\end{tabular}

Note: Significant differences $(\mathrm{p}<0.05)$ between the values in the column are identified by different letters. 
Table 4. Morphological features and yield of hybrid NK Brio.

\begin{tabular}{|c|c|c|c|c|c|c|c|}
\hline Year & $\begin{array}{l}\text { The density of plants' } \\
\text { standing, thousand pc/ha }\end{array}$ & $\begin{array}{l}\text { Yield, } \\
\text { t/ha }\end{array}$ & $\begin{array}{l}\text { Number of seeds, } \\
\text { pc/anthode }\end{array}$ & $\begin{array}{l}\text { Mass of seed, } \\
\text { g/anthode }\end{array}$ & $\begin{array}{l}\text { The diameter of } \\
\text { anthode, } \mathrm{cm}\end{array}$ & $\begin{array}{c}\text { Plant height, } \\
\mathrm{cm}\end{array}$ & $\begin{array}{l}\text { The diameter of } \\
\text { the stem, } \mathrm{cm}\end{array}$ \\
\hline \multirow{5}{*}{2016} & 50 & $3.34^{\mathrm{b}}$ & $826^{\mathrm{b}}$ & $65.3^{\mathrm{bc}}$ & $27.2^{\mathrm{bc}}$ & $167.8^{\mathrm{b}}$ & $3.4^{\mathrm{b}}$ \\
\hline & 55 & $3.63^{\mathrm{b}}$ & $823^{\mathrm{b}}$ & $61.7^{\mathrm{b}}$ & $26.8^{\mathrm{bc}}$ & $168.8^{\mathrm{b}}$ & $3.3^{\mathrm{b}}$ \\
\hline & 60 & $3.98^{\mathrm{a}}$ & $814^{\mathrm{a}}$ & $59.4^{\mathrm{a}}$ & $26.3^{\mathrm{b}}$ & $169.6^{\mathrm{b}}$ & $3.1^{\mathrm{b}}$ \\
\hline & 65 & $3.69^{\mathrm{a}}$ & $769^{a}$ & $55.4^{\mathrm{a}}$ & $24.4^{\mathrm{b}}$ & $169.9^{\mathrm{b}}$ & $3.0^{\mathrm{b}}$ \\
\hline & Average & 3.66 & $808^{\mathrm{b}}$ & $60.4^{\mathrm{b}}$ & $26.2^{\mathrm{b}}$ & $169.0^{\mathrm{b}}$ & $3.2^{\mathrm{b}}$ \\
\hline \multirow{5}{*}{2017} & 50 & $3.20^{\mathrm{bc}}$ & $790^{\mathrm{b}}$ & $60.8^{\mathrm{b}}$ & $26.8^{\mathrm{a}}$ & $167.5^{\mathrm{b}}$ & $3.3^{\mathrm{b}}$ \\
\hline & 55 & $3.41^{b c}$ & $775^{\mathrm{b}}$ & $57.4^{\mathrm{b}}$ & $26.2^{\mathrm{a}}$ & $168.4^{\mathrm{b}}$ & $3.2^{\mathrm{b}}$ \\
\hline & 60 & $3.68^{\mathrm{a}}$ & $764^{\mathrm{b}}$ & $55.0^{\mathrm{b}}$ & $25.7^{\mathrm{a}}$ & $168.9^{\mathrm{b}}$ & $3.2^{\mathrm{ab}}$ \\
\hline & 65 & $3.41^{\mathrm{a}}$ & $748^{\mathrm{ab}}$ & $53.1^{\mathrm{b}}$ & $24.0^{\mathrm{a}}$ & $169.6^{\mathrm{b}}$ & $2.9^{\mathrm{ab}}$ \\
\hline & Average & 3.43 & $769^{\mathrm{b}}$ & $56.6^{\mathrm{b}}$ & $25.7^{\mathrm{a}}$ & $168.6^{\mathrm{b}}$ & $3.2^{\mathrm{ab}}$ \\
\hline \multirow{5}{*}{2018} & 50 & $3.43^{\mathrm{b}}$ & $831^{\mathrm{ab}}$ & $65.6^{\mathrm{bc}}$ & $27.7^{\mathrm{bc}}$ & $168.5^{c}$ & $3.5^{\mathrm{b}}$ \\
\hline & 55 & $3.78^{\mathrm{b}}$ & $828^{\mathrm{ab}}$ & $62.1^{\mathrm{bc}}$ & $27.6^{\mathrm{b}}$ & $169.2^{c}$ & $3.3^{\mathrm{b}}$ \\
\hline & 60 & $4.12^{\mathrm{a}}$ & $827^{\mathrm{ab}}$ & $61.2^{\mathrm{b}}$ & $26.3^{\mathrm{b}}$ & $170.4^{\mathrm{b}}$ & $3.3^{\mathrm{ab}}$ \\
\hline & 65 & $3.92^{\mathrm{a}}$ & $802^{\mathrm{a}}$ & $56.1^{\mathrm{b}}$ & $25.2^{\mathrm{b}}$ & $171.5^{\mathrm{b}}$ & $3.1^{\mathrm{ab}}$ \\
\hline & Average & $3.81^{\mathrm{a}}$ & $822^{\mathrm{ab}}$ & $61.3^{\mathrm{b}}$ & $26.7^{\mathrm{b}}$ & $169.9^{\mathrm{b}}$ & $3.3^{\mathrm{ab}}$ \\
\hline
\end{tabular}

Note: Significant differences $(\mathrm{p}<0.05)$ between the values in the column are identified by different letters.

Table 5. Morphological features and yield of hybrid NK Ferti.

\begin{tabular}{|c|c|c|c|c|c|c|c|}
\hline Year & $\begin{array}{l}\text { The density of plants' } \\
\text { standing, thousand } \mathrm{pc} / \mathrm{ha}\end{array}$ & $\begin{array}{c}\text { Yield, } \\
\text { t/ha }\end{array}$ & $\begin{array}{l}\text { Number of seeds, } \\
\text { pc/anthode }\end{array}$ & $\begin{array}{l}\text { Mass of seed, } \\
\text { g/anthode }\end{array}$ & $\begin{array}{l}\text { The diameter of } \\
\text { anthode, } \mathrm{cm}\end{array}$ & $\begin{array}{l}\text { Plant height, } \\
\mathrm{cm}\end{array}$ & $\begin{array}{c}\text { The diameter of } \\
\text { the stem, } \mathrm{cm}\end{array}$ \\
\hline \multirow{5}{*}{2016} & 50 & $3.04^{\mathrm{ab}}$ & $697^{\mathrm{bc}}$ & $53.0^{\mathrm{ab}}$ & $23.4^{\mathrm{b}}$ & $182.5^{\mathrm{b}}$ & $2.8^{\mathrm{bc}}$ \\
\hline & 55 & $3.10^{\mathrm{ab}}$ & $692^{\mathrm{bc}}$ & $51.2^{\mathrm{ab}}$ & $22.1^{\mathrm{a}}$ & $183.8^{\mathrm{b}}$ & $2.8^{\mathrm{b}}$ \\
\hline & 60 & $3.56^{\mathrm{a}}$ & $689^{b}$ & $51.0^{\mathrm{a}}$ & $20.4^{\mathrm{a}}$ & $185.1^{\mathrm{a}}$ & $2.7^{\mathrm{a}}$ \\
\hline & 65 & $3.24^{\mathrm{a}}$ & $656^{\mathrm{b}}$ & $45.9^{\mathrm{a}}$ & $19.3^{\mathrm{a}}$ & $186.2^{\mathrm{a}}$ & $2.5^{\mathrm{a}}$ \\
\hline & Average & $3.24^{\mathrm{ab}}$ & $684^{\mathrm{b}}$ & $50.3^{\mathrm{a}}$ & $21.3^{\mathrm{a}}$ & $184.4^{\mathrm{b}}$ & $2.7^{\mathrm{b}}$ \\
\hline \multirow{5}{*}{2017} & 50 & $2.70^{\mathrm{bc}}$ & $682^{c}$ & $51.2^{\mathrm{b}}$ & $22.8^{\mathrm{b}}$ & $181.9^{\mathrm{b}}$ & $2.7^{\mathrm{b}}$ \\
\hline & 55 & $2.96^{\mathrm{b}}$ & $678^{\mathrm{bc}}$ & $50.2^{\mathrm{b}}$ & $21.7^{\mathrm{b}}$ & $182.8^{\mathrm{b}}$ & $2.6^{\mathrm{b}}$ \\
\hline & 60 & $3.36^{\mathrm{a}}$ & $671^{\mathrm{b}}$ & $48.3^{\mathrm{bc}}$ & $20.1^{\mathrm{a}}$ & $184.6^{\mathrm{a}}$ & $2.6^{\mathrm{b}}$ \\
\hline & 65 & $3.12^{\mathrm{a}}$ & $659^{\mathrm{b}}$ & $45.5^{\mathrm{b}}$ & $18.5^{\mathrm{a}}$ & $186.1^{\mathrm{a}}$ & $2.5^{\mathrm{b}}$ \\
\hline & Average & $3.04^{\mathrm{b}}$ & $673^{\mathrm{b}}$ & $48.8^{\mathrm{b}}$ & 20.8 & 183.9 & 2.6 \\
\hline \multirow{5}{*}{2018} & 50 & $3.27^{\mathrm{bc}}$ & $706^{\mathrm{bc}}$ & $54.4^{\mathrm{b}}$ & $23.6^{\mathrm{a}}$ & $183.2^{\mathrm{a}}$ & $2.9^{\mathrm{b}}$ \\
\hline & 55 & $3.48^{\mathrm{b}}$ & $701^{\mathrm{bc}}$ & $51.9^{\mathrm{b}}$ & $22.2^{\mathrm{a}}$ & $183.8^{\mathrm{a}}$ & $2.9^{\mathrm{b}}$ \\
\hline & 60 & $3.79^{\mathrm{a}}$ & $698^{\mathrm{b}}$ & $51.0^{\mathrm{b}}$ & $20.7^{\mathrm{a}}$ & $186.4^{\mathrm{a}}$ & $2.8^{\mathrm{a}}$ \\
\hline & 65 & $3.66^{\mathrm{a}}$ & $663^{\mathrm{b}}$ & $46.4^{\mathrm{a}}$ & $19.8^{\mathrm{a}}$ & $187.2^{\mathrm{a}}$ & $2.6^{\mathrm{a}}$ \\
\hline & Average & $3.55^{\mathrm{a}}$ & $692^{\mathrm{b}}$ & $50.9^{\mathrm{b}}$ & $21.6^{\mathrm{a}}$ & $185.2^{\mathrm{a}}$ & 2.8 \\
\hline
\end{tabular}

Note: Significant differences $(\mathrm{p}<0.05)$ between the values in the column are identified by different letters. 


\subsection{Correlative Dependence of Hybrids' Yield and Sowing Structure}

With a positive correlation between yield and plant density, we found an inverse correlation of different strength relationship between yield and number of seeds in the anthode: Ukrainskyi F1 $-r=-0.957-0.987$; P63LL06-r $=-0.333-0.864$; NK Brio- $r=-0.262-0.552$; NK Ferti- $r=-0.164-0.623$ in years with different weather conditions (Table 6).

Seed differentiation in anthodes has an inverse correlation to the density of plants' standing $(r=-0.935)$. With plant density increasing, the number of seeds in the anthodes decreases. This dependence was observed for all studied hybrids.

The yield of sunflower hybrids directly depends on the leaf surface index, but for hybrids this dependence is different. Correlation between these indicators for hybrid Ukrainskyi F1 is close $(r=0.965)$; NK Ferti- $r=0.757$; P63LL06- $r=$ 0.689 ; NK Brio $-r=0.680$. So, it can be argued that the yield potential of hybrids P63LL06, NK Ferti, NK Brio depends on the increase of the leaf surface index. Sowings of hybrid Ukrainskyi F1 form the leaf surface area, which ensures the realization of the biological potential of the hybrid.

Table 6. Correlation dependences of yield and morphological characteristics of sunflower plants.

\begin{tabular}{|c|c|c|c|c|c|c|c|c|}
\hline \multirow{2}{*}{ Hybrid } & \multirow{2}{*}{ Year } & \multicolumn{7}{|c|}{ Connections $^{1}$} \\
\hline & & $\mathrm{Y}^{\star} \mathrm{D}$ & $\mathrm{Y}^{\star} \mathrm{N}$ & $N^{\star} \mathrm{D}$ & $\mathrm{Y}^{\star} \mathrm{W}$ & $\mathrm{H}^{\star} \mathrm{D}$ & $\mathrm{Y}^{\star} \mathrm{H}$ & $\mathrm{Y}^{\star} \mathrm{IL}$ \\
\hline \multirow[t]{4}{*}{ Ukrainskyi F1 } & 2016 & 0.989 & -0.957 & -0.978 & -0.989 & 0.989 & 0.973 & 0.986 \\
\hline & 2017 & 0.998 & -0.971 & -0.969 & -0.998 & 0.996 & 0.996 & 0.999 \\
\hline & 2018 & 0.977 & -0.984 & -0.974 & -0.912 & 0.986 & 0.928 & 0.971 \\
\hline & Average & 0.988 & -0.971 & -0.974 & -0.966 & 0.990 & 0.965 & 0.986 \\
\hline \multirow[t]{4}{*}{ P63LL06 } & 2016 & 0.709 & -0.333 & -0.897 & -0.597 & 0.997 & 0.736 & 0.639 \\
\hline & 2017 & 0.882 & -0.864 & -0999 & -0.882 & 0.992 & 0.863 & 0.869 \\
\hline & 2018 & 0.651 & -0.478 & -0.966 & -0.537 & 0.997 & 0.665 & 0.559 \\
\hline & Average & 0.747 & -0.558 & -0.954 & -0.672 & 0.995 & 0.775 & 0.689 \\
\hline \multirow[t]{4}{*}{ NK Brio } & 2016 & 0.689 & -0.262 & -0.877 & -0.825 & 0.976 & 0.823 & 0.681 \\
\hline & 2017 & 0.804 & -0.552 & -0.998 & -0.730 & 0.994 & 0.599 & 0.537 \\
\hline & 2018 & 0.804 & -0.363 & -0.845 & -0.737 & 0.994 & 0.766 & 0.822 \\
\hline & Average & 0.766 & -0.392 & -0.907 & -0.764 & 0.988 & 0.729 & 0.680 \\
\hline \multirow[t]{4}{*}{ NK Ferti } & 2016 & 0.589 & -0.164 & -0.873 & -0.234 & 0.999 & 0.616 & 0.633 \\
\hline & 2017 & 0.773 & -0.623 & -0.973 & -0.640 & 0.992 & 0.749 & 0.788 \\
\hline & 2018 & 0.846 & -0.474 & -0.869 & -0.777 & 0.967 & 0.883 & 0.851 \\
\hline & Average & 0.736 & -0.421 & -0.905 & -0.551 & 0.986 & 0.749 & 0.757 \\
\hline
\end{tabular}

Note. Y-yield; D-density of plants' standing; $\mathrm{N}-$ number of seeds in the anthode (on the plant), W-the weight of 1000 seeds; $\mathrm{H}-$ plants height; IL-leaf surface index. Actual at $\mathrm{P}<0.01$. 


\section{Discussion}

Studies show growing of sunflower hybrids in the Northern part of the Forest-Steppe of Ukraine is highly efficient. Yield potential realization is quite high, which is provided by the necessary amounts of positive, active, and effective temperatures and sufficient precipitation. Determining the coefficients of plasticity and plasticity allows us to identify stable sunflower hybrids, hybrids with a high level of plasticity and to recommend them for production in the growing regions. Adaptive technological factors cause increased stability of yield's sunflower hybrids.

\section{Conclusions}

Due to the formation of sunflower agrocenosis with optimal plant density provides an increase in its productivity.

Sunflower hybrids can be divided into several groups, according to the peculiarities of yield formation: 1) yield increases only due to sowings thickening-Ukrainskyi F1;2) combined efficiency-due to increasing the density of sowings up to 60 thousand plants/ha and generative organs formation-NK Brio; 3) hybrids of intermediate type-NK Ferti and P63LL06.

The optimal density of early-maturing hybrids plants standing is not less than 65 thousand pieces/ha and of medium-ripe hybrids-the optimal density-60 thousand pieces/ha.

\section{Conflicts of Interest}

The authors declare no conflicts of interest regarding the publication of this paper.

\section{References}

[1] IPCC (2007) Climate Change: Synthesis Report. Contribution of Working Groups I, II and III to the Fourth Assessment Report of the Intergovernmental Panel on Climate Change. IPCC, Geneva.

[2] Makareviciene, V., Kalenska, S., Skorupskaite, V., Yunik, A. and Gumbyte, M. (2013) The Use of Oilseed Meal for the Production of Biogas. The 6 th International Scientific Conference, Akademija, 28-29 November 2019, 75-78.

[3] Sala, O., Chapin, F., Armesto, J., Berlow, E. and Bloomfield, J. (2000) Global Biodiversity Scenarios for the Year 2100. Science, 287, 1770-1774.

https://doi.org/10.1126/science.287.5459.1770

[4] Schwartz, M. (1992) Potential Effects of Global Climate Change on the Biodiversity of Plants. The Forestry Chronicle, 68, 462-471. https://doi.org/10.5558/tfc68462-4

[5] Sendžikienė, E., Makarevičienė, V. and Kalenska, S. (2012) Exhaust Emissions from the Engine Running on Multi-Component Fuel. Transport, 27, 111-117. https://doi.org/10.3846/16484142.2012.690138

[6] Eremenko, O.A., Kalitka, V.V., Kalenska, S.M. and Malkina, V.M. (2018) Assessment of Ecological Plasticity and Stability of Sunflower Hybrids (Helianthus annuus L.) in Ukrainian Steppe. Ukraine Journal of Ecology, 8, 289-296. 
https://doi.org/10.15421/2018_214

[7] Melnyk, A., Akuaku, J., Trotsenko, V. and Melnyk, T. (2019) Productivity and Quality of High-Oleic Sunflower Seeds as Influenced by Foliar Fertilizers and Plant Growth Regulators in the Left-Bank Forest-Steppe of Ukraine. AgroLife Scientific Journal, 8, 167-174.

[8] Debaeke, P., Casadebaig, P., Flenet, F. and Langlade, N. (2017) Sunflower Crop and Climate Change: Vulnerability, Adaptation, and Mitigation Potential from Case-Studies in Europe. OCL, 24, Article No. D102. https://doi.org/10.1051/ocl/2016052

[9] Yeremenko, O., Kalenska, S. and Kalytka, V. (2018) Safflower Productivity Depending on Seed Treatment by AKM Plant Growth Regulator and Level of Mineral Nutrition. Agriculture \& Forestry, 64, 65-72. https://doi.org/10.17707/AgricultForest.64.1.08

[10] Bavec, F. and Bavec, M. (2002) Effects of Plant Population on Leaf Area Index, Cob Characteristics and Grain Yield of Early Maturing Maize Cultivars (FAO100-400). European Journal of Agronomy, 16, 151-159. https://doi.org/10.1016/S1161-0301(01)00126-5

[11] Calamai, A., Masoni, A., Palchetti, E., Grassi, C. and Brilli, L. (2018) Evaluation of Agronomic Performance and Seed Oil Composition of Sunflower Genotypes in South Madagascar. Agricultural Sciences, 9, 1337-1353. https://doi.org/10.4236/as.2018.910093

[12] Canavar, Ö., Ellmer, F. and Chmielewski, F.M. (2010) Investigation of Yield and Yield Components of Sunflower (Helianthus annuus L.) Cultivars in the Ecological Conditions of Berlin (Germany). Helia, 33, 117-130. https://doi.org/10.2298/HEL1053117C

[13] Beg, A., Pourdad, S.S. and Alipour, S. (2007) Row and Plant Spacing Effects on Agronomic Performance of Sunflower in Warm and Semi-Cold Areas of Iran. $\mathrm{He}$ lia, 30, 99-104. https://doi.org/10.2298/HEL0747099B

[14] Gonzáles, J., Mancuso, N. and Ludueña, P. (2013) Sunflower Yield and Climatic Variables. Helia, 36, 69-76. https://doi.org/10.2298/HEL1358069G

[15] Rosenberg, N. (1992) Adaptation of Agriculture to Climate Change. Climatic Change, 21, 385-405. https://doi.org/10.1007/BF00141378

[16] Pissai, C. (2011) Stability of Yield and Other Characters of Sunflower across Environments. Suranaree Journal Science and Technology, 18, 55-60.

[17] Tahir, M.H.N., Imran, M. and Hussain M.K. (2002) Evaluation of Sunflower (Helianthus annuus L.) Inbred Lines for Drought Tolerance. International Journal of Agriculture and Biology, 3, 398-400.

[18] Ali, H.P., Laghari, G.M., Kaleri, A.A., Soothar, M.K., Kumar, J.S., Mukhtar, M.R., Abro, A. and Soothar, J.K. (2017) Effects of Seed Rates on the Growth and Yield of Different Sunflower Varieties. Pure and Applied Biology, 6.

[19] Miller, J.F. and Fick, C.N. (1978) Influence of Plant Population on Performance of Sunflower Hybrids. Canadian Journal of Plant Science, 58, 597-600.

https://doi.org/10.4141/cjps78-093

[20] Nel, A.A., Loubser, H.L. and Hammes, P.S. (2000) The Effect of Plant Population on the Quality of Sunflower Seed for Processing. South African Journal of Plant and Soil, 17, 6-9. https://doi.org/10.1080/02571862.2000.10634858

[21] Andrade, A., Vigliocco, A., Alemano, S., Llanes, A. and Abdala, G. (2013) Comparative Morpho-Biochemical Responses of Sunflower Lines Sensitive and Tolerant to Water Stress. American Journal of Plant Sciences, 4, 156-167. 
https://doi.org/10.4236/ajps.2013.412A3018

[22] Ion, V., Dicu, G., Basa, A.G., Dumbrava, M., Temocico, G., Epure, L.I. and State, D. (2015) Sunflower Yield and Yield Components under Different Sowing Conditions. Agriculture and Agricultural Science Procedia, 6, 44-51. https://doi.org/10.1016/j.aaspro.2015.08.036

[23] McMaster, G.S., Buchleiter, G.W. and Bausch, W.C. (2012) Relationships between Sunflower Plant Spacing and Yield: Importance of Uniformity in Spacing. Crop Science, 52, 309-319. https://doi.org/10.2135/cropsci2010.10.0572

[24] Mijic, A., Liovic, I., Kovacevic, V. and Pepo, P. (2020) Impact of Weather Conditions on Variability in Sunflower Yield over Years in Eastern Parts of Croatia and Hungary. Acta Agronomica Hungarica, 60, 397-405.

https://doi.org/10.1556/AAgr.60.2012.4.10

[25] Diepenbrock, W., Lang, M. and Feil, B. (2001) Yield and Quality of Sunflower as Affected by Row Orientation, Row Spacing and Plant Density. Die Bodenkultur, 52, 29-36.

[26] Ibrahim, H.M. (2012) Response of Some Sunflower Hybrids to Different Levels of Plant Density. APCBEE Procedia, 4, 175-182.

https://doi.org/10.1016/j.apcbee.2012.11.030

[27] Agele, S.O. (2003) Response of Sunflower to Weather Variations in a Tropical Rainforest Zone. African Crop Science Conference Proceedings, Vol. 6, 1-8.

[28] Gholinezhad, E., Aynaband, A. and Hassanzade, A. (2009) Study of the Effect of Drought Stress on Yield, Yield Components and Harvest Index of Sunflower Hybrid Iroflor at Different Levels of Nitrogen and Plant Population. Notulae Botanicae Horti Agrobotanici Cluj-Napoca, 37, 85-94.

[29] Ion, V., Dicu, G., Băúa, A.G. and State, D. (2013) Yield Components at Some Hybrids of Sunflower (Helianthus annuus L.) under Drought Conditions from South Romania. AgroLife Scientific Journal, 2, 9-14.

[30] Ahmad, M., Ali, A., Khan, A., Sher, A., Rashid, A., Jamro, S., Ur-Rahman, S. and Ahmad, S. (2017) Nitrogen Management of Diverse Sunflower (Helianthus annus L.) Hybrids Production under Agro-Climatic Conditions of Sargodha, Pakistan. American Journal of Plant Sciences, 8, 1357-1367. https://doi.org/10.4236/ajps.2017.83028

[31] Haseeb, M. and Maqbool, N. (2015) Influence of Foliar Applied Nitrogen on Reproductive Growth of Sunflower (Helianthus annuus L.) under Water Stress. Agricultural Sciences, 6, 1413-1420. https://doi.org/10.4236/as.2015.612137

[32] Oad, K.R., Ali, A.M., Jagdesh, K. and Dilpat, R.M. (2018) Effect of Foliar Applied Urea on Growth and Yield of Sunflower (Helianthus annuus L.). Open Access Library Journal, 5, e4668. https://doi.org/10.4236/oalib.1104668

[33] Xiao, S., Chen, S.Y., Zhao, L.Q. and Wang, G. (2006) Density Effects on Plant Height, Growth and Inequality in Sunflower Population. Journal of Integrative Plant Biology, 48, 513-519. https://doi.org/10.1111/j.1744-7909.2006.00265.x

[34] Li, J.G., Qu, Z.Y., Chen, J., Yang, B. and Huang, Y.P. (2019) Effect of Planting Density on the Growth and Yield of Sunflower under Mulched Drip Irrigation. Water, 11, 751. https://doi.org/10.3390/w11040752

[35] Soleymani, A. (2017) Light Response of Sunflower and Canola as Affected by Plant Density, Plant Genotype and N Fertilization. Journal of Photochemistry and Photobiology B: Biology, 173, 580-588. https://doi.org/10.1016/j.jphotobiol.2017.06.038

[36] Ali, A., Ahmad, A., Khaliq, T., Ali, A. and Ahmad, M. (2013) Nitrogen Nutrition and Planting Density Effects on Sunflower Growth and Yield: A Review. Pakistan 
Journal of Nutrition, 12, 1024-1035. https://doi.org/10.3923/pjn.2013.1024.1035

[37] Ali, S.S., Manzoor, Z., Awan, T.H. and Mehdi, S.S. (2006) Evaluation of Performance and Stability of Sunflower Genotypes against Salinity Stress. Journal of Animal and Plant Sciences, 16, 47-51.

[38] Allam, A.Y., El-Nagar, G.R. and Galal, A.H. (2002) Response of Two Sunflower Hybrids to Planting Dates and Densities. Acta Agronomica Hungarica, 51, 25-35. https://doi.org/10.1556/AAgr.51.2003.1.4

[39] Barros, J.F.C., De Carvalho, M. and Basch, G. (2004) Response of Sunflower (Helianthus annuuss L.) to Sowing Date and Plant Density under Mediterranean Conditions. European Journal of Agronomy, 21, 347-356.

https://doi.org/10.1016/j.eja.2003.10.005

[40] Ieremenko, O. and Kalitka, V. (2016) Productivity of Sunflower Hybrids (Helianthus annuus L.) under the Effect of AKM Plant Growth Regulator in the Conditions Low Moisture of Southern Steppe of Ukraine. Journal of Agriculture and Veterinary Science, 9, 59-64. https://doi.org/10.9790/2380-0909015964

[41] Eberhart, S.A. and Russel, W.A. (1966) Stability Parameters for Comparing Varieties. Crop Science, 6, 36-40.

https://doi.org/10.2135/cropsci1966.0011183X000600010011x 